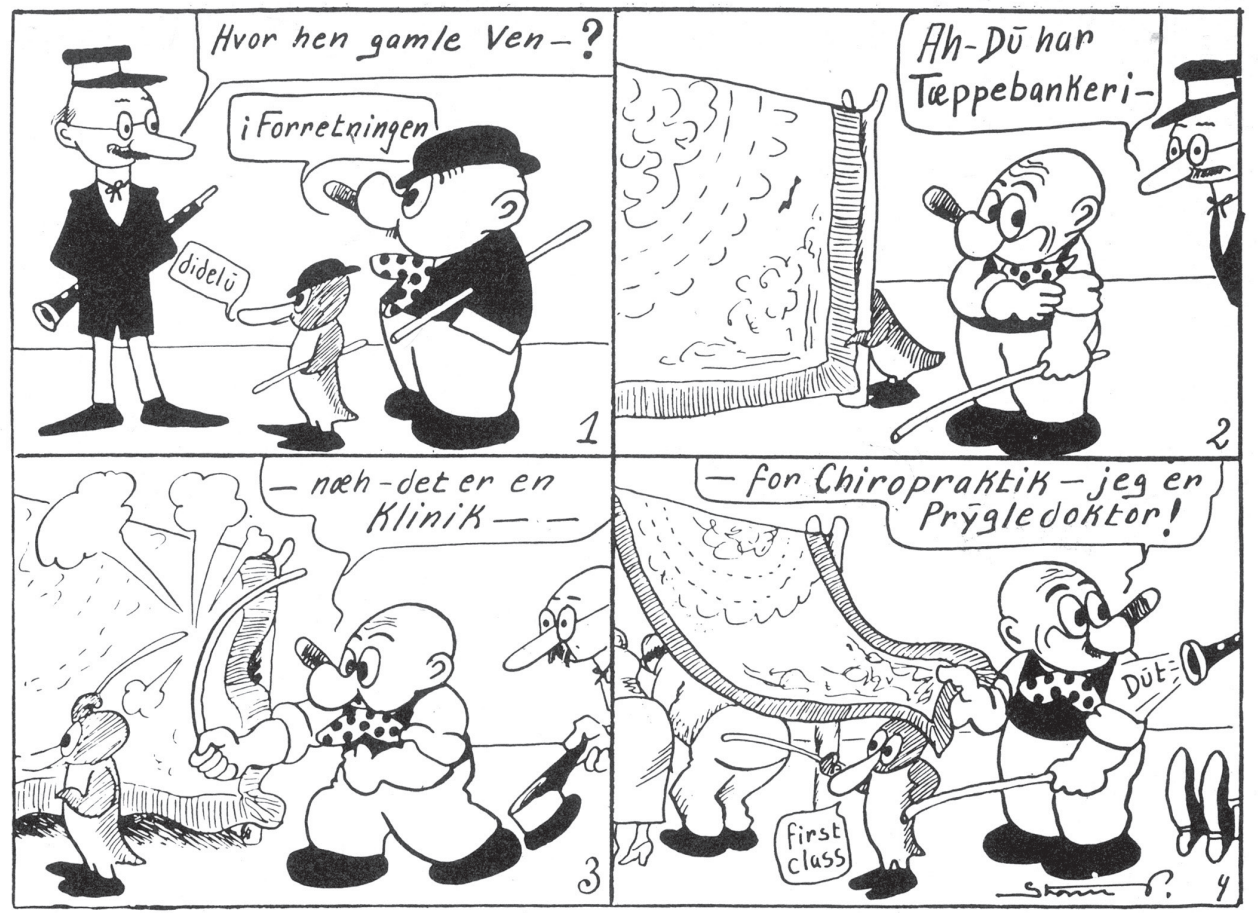

Storm P. illustrerer her, at kiropraktoren af nogen opfattedes som prygledoktor.

Den første kiropraktorklinik åbnede i Danmark i 1920, og fra start delte behandlingen vandene. På den ene side var tilstrømningen af patienter stor, på den anden side florerede alverdens fordomme om, hvad den kiropraktiske behandling egentlig gik ud på. I flere år kaldte folkeviddet således kiropraktorer for "prygledoktorer« fordi en udbredt fordom hævdede, at de slog deres patienter med stok.

\title{
Kroppen under behandling - Gymnastikken, fysioterapien, kiropraktikken og laegevidenskaben ca. 1900-1930
}




\section{INDLEDNING}

I begyndelsen af det 20. århundrede blev gymnastik med udgangspunkt i den svenske variant samt fysioterapi ${ }^{1}$ og kiropraktik etableret herhjemme i henholdsvis skolesystemet (gymnastik) og behandlersystemet (fysioterapi og kiropraktik). Historien om de tre former for behandling/aktivitet (herefter "aktivitet«) er blevet selvstændigt beskrevet før, men det er her første gang, de behandles samlet. ${ }^{2}$ Det er denne artikels overordnede hypotese, at en samlet undersøgelse af de tre aktiviteter, som har kroppen som genstand, og som har en fælles ambition om at forbedre sundhed i bred forstand, kan øge vores generelle viden om relationen (læge)videnskab, krop og bevægelse i det moderne samfund.

Kiropraktik og fysioterapi fremstår umiddelbart som forholdsvis veldefinerede aktiviteter med veldefinerede metoder. De er desuden begge del af et behandlersystem. Sammenlignet hermed dækker begrebet og faget idræt over et væld af forskellige aktiviteter, der også udøves som fritidsaktivitet, på forskellige niveauer, og som bortset fra selve det fysiske element ikke nødvendigvis har noget til fælles. I denne artikel er gymnastik i den svenske variant blevet valgt som idrætscase. Et væld af idrætsaktiviteter blev (også) for 100 år siden generelt knyttet til sundhed, men netop gymnastik blev tillagt særlige og konkrete sundhedsvirkninger, der yderligere blev hævdet at være videnskabeligt baseret og bevist, og som derfor gjorde netop denne aktivitet særligt udsat for lægevidenskabelig vurdering (Jørgensen, 1998, s. 126-129).

\section{PERIODENS VIDENSKABSTEORETISKE BAGGRUND OG ARTIKLENS TEMAER}

De tre aktiviteter havde som fælles udgangspunkt, at sundhed og helbredelse kunne opnås gennem bevægeapparatet ved hjælp af manipulation og bevægelse af led og muskler. Det var ikke i sig selv nyt at søge at behandle, forme og forbedre ved hjælp af krop og bevægelse, det havde man gjort i århundreder. Det nye bestod $\mathrm{i}$, at alle tre aktiviteter hævdede at hvile på moderne videnskabelig grund og yderligere kunne søge legitimitet $i$, at undervisningen blev foretaget på autoriserede institutter og højere læreanstalter. De tre aktiviteter hævdede yderligere at kunne helbrede ikke kun sygdom og skavank i bevægeapparat og muskulatur, men også i de indre organer. Idéverdenen var, at det var den ydre bevægelse i sig selv, der, hvis den blev korrekt udført og doseret, også skabte orden i legemets indre ubalance(r). Idræt og kiropraktik havde endelig det til fælles, at de mente, at ikke kun fysiske og fysiologiske ubalancer, men også mentale kunne helbredes gennem bevægelse. Det mente den autoriserede del af fysioterapien dog ikke, hvorimod en sand underskov af uautoriserede massører langtfra var afvisende over for den tanke.

Opsamlende kan man sige, at såvel gymnastikken og fysioterapien som kiropraktikken tog udgangspunkt i anatomien. Alle tre aktiviteter ønskede, med lidt forskellig pointering, at opøve, bibeholde eller genskabe funktioner i krop og bevægeapparat via kroppens ydre bevægelser, og der blev lagt vægt på kroppens udseende og holdning. Med lidt god vilje kunne alle tre aktiviteter således tilknyttes den videnskabelige retning, ortopædi, der netop levede op til de fleste af ovennævnte karakteristika, idet den dog ikke (som gymnastikken og fysioterapien) hævdede at kunne helbrede mental sygdom. Den eksperimentelle fysiologi, som er den form for videnskab, der kommer nærmest den lægevidenskab, der omtales i denne artikel, blev udviklet senere end ortopædien. Fysiologien inte- 
resserer sig især for kroppens indre processer, og den havde som videnskab betragtet stor ekspansionskraft og forklaringskraft fra ca. 1900 (Lindroth, 2004, s. 98). At hævde videnskabeligt bevist sundhedsfremme og helbredelse i bred forstand gennem ydre bevægelse og manipulation var således ikke uproblematisk, hvis man ville tages alvorligt for ca.100 år siden af lægevidenskaben.

Den naturvidenskabelige metode, som både ortopædien og fysiologien benyttede, var i løbet af 1800-tallet i stigende grad kommet til at repræsentere idealet om videnskabelighed, og positivismen som videnskabsopfattelse og dens krav om videnskabelig eksakthed og objektivitet kom i slutningen af århundredet til at stå centralt. Det skal pointeres, at også gymnastikken, fysioterapien og kiropraktikken var enige heri. Det var udelukkende definitionen af videnskabelighed, validitet, eksakthed og objektivitet, man diskuterede. Den naturvidenskabelige metode havde gået sin sejrsgang og kunne afsløre de lovmæssige sammenhænge inden for såvel den fysiske, som den sociale verden, mente man. Der var således i et vist omfang tale om en generel metode.

Inspireret af Foucault har Bente Rosenbeck påpeget, hvorledes det politiske paradigme med historie som en central videnskab blev knyttet til den offentlige sfære, mens det kropslige blev henvist til den private sfære som genstandsfelt for naturvidenskab og medicin (2009, s. 24-25). Kroppen blev således lidt firkantet sagt overladt til lægerne og til deres forståelse af (natur)videnskab. De tre aktiviteter, i højere grad dog den svenske gymnastik og kiropraktikken end fysioterapien, påberåbte sig alt i alt gennem deres ydre behandling af kroppen resultater, der på afgørende punkter var på kollisionskurs med den moderne lægevidenskabs krav til ordentlig videnskab.

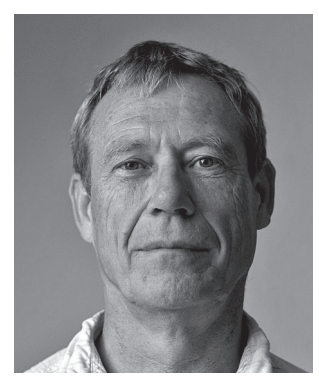

AF

PER JORGENSEN

Tema I: Det første formål med denne artikel er at undersøge de tre aktiviteters forhold til (læge)videnskaben i perioden inden for to områder, hvor det første handler om definition det andet om relation: Hvorledes benyttede lægevidenskaben sin magtposition over for de tre aktiviteter i forhold til at definere områder som videnskabelighed, sundhed og helbredelse? Hvad kendetegnede forholdet mellem ekspert (læge, kiropraktor, fysioterapeut eller underviser) og lægmand (patient eller elev)?

På Institut for Idræt og Biomekanik ved Syddansk Universitet i Odense er i vore dage samlet tre aktiviteter: idræt, fysioterapi og kiropraktik. Instituttet er placeret i Det sundhedsvidenskabelige Fakultet, og dets forskning, undervisning og vidensdeling ønsker ifølge hjemmesiden at skabe ny viden inden for to områder, "humane bevægelser« og »bevægeapparatet i bredeste forstand «. Sidstnævnte område beskæftiger sig især med forebyggelse, sundhedsfremme, behandling, genoptræning og rehabilitering. Det ser således ud til, at der kan være synergieffekter ved at samle idræt, kiropraktik og fysioterapi i et fælles institut under et fakultet, hvor den meget store storebror hedder »lægevidenskab«. I denne artikels periode var det langtfra indlysende, vel nærmest utænkeligt, at gymnastik (eller, som det er tilfældet i Odense, idræt), fysioterapi og kiropraktik skulle havne a) sammen 
$\mathrm{i}$ et b) universitetsmiljø, domineret af c) laegevidenskab.

Tema II: Det andet formål med artiklen er derfor (meget) kort at beskrive de tre aktiviteters udvikling efter ca. 1930: Hvilken vej tog de tre aktiviteter, og hvad er den faglige baggrund for, at de i vore dage kan findes på institut sammen i et lægevidenskabeligt domineret universitetsmiljø?

\section{HISTORIOGRAFI, METODE OG TEORI}

Modsat gymnastikken er fysioterapiens historie herhjemme kun sparsomt beskrevet. Kiropraktikkens historie er velbeskrevet før ca. 1940, men ikke efter. Der vil af pladshensyn ikke blive foretaget en historiografisk redegørelse for de tre aktiviteter, men væsentlige dele af den centrale litteratur vil blive anvendt $i$ artiklen.

Metoden kan kort beskrives som komparation af temaer lokaliseret ved hjælp af hermeneutik og diskursanalyse. Hvad teori angår, vil det fremgå af artiklen, at der som baggrundsforståelse trækkes på Michel Foucault, idet det dog skal pointeres, at artiklen hverken gennemgår, endsige diskuterer, hans teorier. Artiklen beskæftiger sig bl.a. med "kampen " mellem lægevidenskaben og de tre aktiviteter om definitionsmagten $^{3}$ til videnskabelighed og om forholdet mellem lærd (læge, kiropraktor, fysioterapeut eller underviser) og ulærd (patient/ elev). I begge tilfælde er inspiration fundet i Foucaults ideer til henholdsvis "magtens former« (hvem har f.eks. retten til "at tale«) og »klinikkens fødsel« (billedet af patient og læge, der mødes, erstattes over tid med billedet af lægen som videnskabsmand, der undersøger et objekt). Der er dog også, som det vil fremgå, trukket på andre teoretikere.

\section{GYMNASTIKKEN}

Idrætshistorikere har brugt mange kræfter på at forklare, hvorfor de grundtvigianske bønder fra 1884 frivilligt begyndte at dyrke den disciplinerende svenske gymnastik, som man i alle andre lande havde måttet gøre obligatorisk i skole og hær for overhovedet at kunne få indført. ${ }^{4}$ Forklaringen er først og fremmest kulturel, idet den svenske gymnastik blev et kropskulturelt samlingspunkt for den del af landbefolkningen, der havde grundtvigianisme, højskole, andelsbevægelse og partiet Venstre som kendetegn, og som stod i politisk modsætning til partiet Højre. Venstre kom til magten i 1901, og forordninger gav i de følgende år den svenske gymnastik en officiel særstatus i alle offentlige skoleformer (folkeskole, gymnasium) samt ved læreanstalterne (seminarium, statens gymnastikinstitut og forsvarets gymnastikskole) (Jørgensen, 1998b, s. 52). ${ }^{5}$ Den svenske gymnastik havde, i hvert fald officielt, stor dominans i skolesammenhæng herhjemme helt frem til skolereformerne i 1930'erne. ${ }^{6}$

\section{DEN VIDENSKABELIGE FUNDERING OG FORHOL- DET MELLEM LAERER OG ELEV}

Gymnastikkens videnskabskriterium stammede fra en tid, hvor det i princippet ikke var i uoverensstemmelse med de daværende normalvidenskabelige krav. Det vil f.eks. sige, at det var valid videnskabelig argumentation at påpege, at gymnastikkens dokumenterede "virkning" bestod i, at gymnastik som aktivitet kunne hævdes at være logisk og stringent opbygget, at den havde formulerede videnskabelige ambitioner, at diskussionerne om den førtes i videnskabelige termer, og at den havde et positivistisk islæt $\mathrm{i}$ og med, at den var erfaringsbaseret (Lindroth, 2004, s. 77). Yderligere blev der ofte brugt analogi til at fremme argumentationen, f.eks. at op- 
træning af muskelceller ligeledes ville optræne hjerneceller via det fælles blod- og nervesystem (Gymnastikkommissionen, 1899, ss. 2-3).

Der blev argumenteret for den svenske gymnastiks fortrin på tre niveauer. Det første hævdede, at gymnastikken byggede på anatomi, fysiologi og patologi. Den var med andre ord naturvidenskabeligt (lægevidenskabeligt) funderet. Gennem sit øvelsesvalg kunne læreren fjerne spændinger, uharmonier og ubalancer i krop og organer. Gymnastikken var dermed hygiejnisk og terapeutisk i sit udgangspunkt, og kropslig harmoni var målet. De to andre niveauer var henholdsvis et social-kulturelt, hvor det blev argumenteret, at gymnastikken var for alle, demokratisk og folkelig, samt et åndeligt, der så gymnastikken som et middel til at gøre sindet rankt og frit.

Samlet set blev der, først i gymnastikbevægelsen og efter århundredskiftet også i skolesammenhæng, argumenteret for den svenske gymnastiks virkning ud fra to bastioner. På den ene side ud fra en snæver videnskabelig tankegang: at der findes anatomisk-fysiologisk korrekte kropsholdninger og -bevægelser, og ud fra en bredere kulturel tankegang: at de rette kropsholdninger og -bevægelser forløser åndelige værdier og holdninger (Korsgaard, 1986, s. 18).

Også lærerens forhold til eleven er beskrevet i videnskabelige termer. Det fremgår bl.a. af beskrivelsen af øvelser og arbejdsanvisninger samt af lærerens rolle i forhold til eleven: "Efter hans (lærerens) Ordre udføres enhver af Bevægelserne. Der kommer et vist mekanisk, fast Præg over det hele ... der kan holdes nøje Overblik over, hvad der er gjort, og hvad der endnu bør gøres. Hver enkelt Muskel kan ... faa nøjagtigt, hvad der tilkommer den, ligesom man her kan passe paa, at den enkelte Bevægelse føres ud til den yderste Grænse af Bevægelsesbanen, hvorved netop den rette Holdning og Udformning af Legemet vindes« (Gymnastikkommissionen, 1899, s. 279). Man kan sige, at beskrivelsen af den praktiske udførelse af gymnastikken her søger at fremmane et billede af en observerende og undersøgende videnskabsmand (læreren) og en række forsøgspersoner (eleverne), der er objekter for hans kliniske blik i en laboratoriesituation (undervisningen), der demonstrerer validitet og reliabilitet $i$ forhold til det videnskabelige resultat (den tilstræbte legemsudvikling).

Netop opnåelsen af den nævnte »rette holdning «, hvis fornemste kendetegn var den rette ryg, var et udtryk for om den anden del af fordelen ved svensk gymnastik, den, der argumenterede med udgangspunkt i kulturel-åndelig gevinst, var blevet høstet: „Et Folk, der har Dristighed samt de nærtbeslægtede Egenskaber: Højsindethed og Trofasthed som Karaktermærke vil ogsaa som Helhed have en god Holdning, medens fejge, lavttænkende og lumske Folk gennemgaaende bliver Grimrianer « (Rud, 1906, s. 78). Således gik naturvidenskabelige og mentale gevinster hånd $\mathrm{i}$ hånd $\mathrm{i}$ den svenske gymnastik, der ifølge tilhængerne sikrede sine udøvere en rank, stærk krop med et ædelt indre. I bogstavelig forstand blev udøverne til retlinede personer.

\section{GYMNASTIIKKEN OG LAEGEVIDENSIKABEN}

Forholdet mellem den svenske gymnastik og lægevidenskaben i Danmark er ofte blevet personificeret gennem »kampen « mellem K.A. Knudsen (cand. theol., praktisk pædagog og statens gymnastikinspektør 1904-1934) og Johannes Lindhard (dr.med., eksperimentel fysiolog og professor fra 1917). Knudsen var leder af den praktiske idrætsuddannelse i Danmark fra 1898 og herunder forstander på Statens Gymnastikin- 
stitut i København fra 1911 til 1927. Lindhard var leder af den teoretiske idrætsuddannelse og -forskning på Københavns Universitet (19091938). Kampens kronologiske forløb og personligt prægede indhold skal ikke gennemgås her, men resultatet kan bruges til at illustrere den tids uenighed om definitionen af naturvidenskab (Jørgensen, 1998a, s. 126-136).

Den svenske gymnastik fik lov til at være i fred for (læge)videnskabelig kritik indtil et stykke ind i 1900-tallet. Selve kampen forløb ca. 1910-1930. Den svenske gymnastik havde med sin hævdelse af at hvile på videnskabelig grund og at have videnskabeligt baseret virkning af både fysisk og mental art længe stukket hovedet langt frem i en tid, hvor nye krav til videnskabelighed var dukket op. Dette "gamle" videnskabssyn, som er uddybet i forrige afsnit, var tiden ved at løbe fra omkring 1900 til fordel for en mere moderne naturvidenskabelighed, der underkendte tradition, praktisk erfaring, vidtløftig analogi og i stedet hvilede på kontrolleret eksperiment. Den videnskabelige sandhed fandtes i laboratorierne, og for en moderne fysiolog var kroppen ikke et instrument for korrekt og smuk holdning, men en maskine, der helst skulle være velfungerende. Når en kropsøvelses værdi skulle bedømmes, skulle det derfor være med udgangspunkt $\mathrm{i}$ en moderne fysiologisk vurdering (Lindroth, 2004, ss. 96-98, 116).

Den moderne fysiologi bevæbnet med resultaterne fra udførte eksperimenter skød den svenske gymnastik ned. En række øvelser og holdningsforskrifter og ikke mindst de påståede virkninger hvilede på falsk og uvidenskabelig grund, mente Lindhard: "Hvorvidt Gymnastikken ogsaa bringer Sundhed, virker profylaktisk mod de almindeligt forekommende Sygdomme, saaledes som det oftest ... fremhæves, maa ... forblive et aabent Spørgsmaal; der foreligger mig bekendt, ikke noget statistisk udarbejdet Iagttagelsesmateriale i saa Henseende« (Citat (1914), fra: Trangbæk og Jørgensen, 2009, s. 92). I årenes løb strammede han yderligere sin afstandstagen til gymnastikkens påståede videnskabelighed (Jørgensen, 1998a, s. 126). Selv om det var Lindhard og den moderne lægevidenskab, der vandt, har også den rykket sig siden. $\mathrm{Ny}$ viden er kommet til. Således udtalte professor og idrætsfysiolog Bengt Saltin i 1994, at »det var et problem, at det var Lindhard, der vandt, for det var overordnet set Knudsen, der havde ret, i al fald hvad angår sammenhængen mellem idræt og sundhed« (Trangbæk og Jørgensen, 2009, s. 100).

I vore dage er humanistiske, samfundsmæssige og idrætspraktiske vinkler almindelige i idrætsundervisningen og -forskningen, og ikke mindst idrættens sundhedsfremmende og rehabiliterende potentialer gør den attraktiv i en sundhedstid.

Den nuancering i standpunkter, som Saltin kunne have ønsket sig, lå imidlertid ikke lige for. For det første manglede der viden inden for området, for det andet stod "kampen « også om definitionsmagtens over idrættens videnskabelighed og om kontrollen med (skole)ungdommens sundhed. Slutningen af det 19. århundrede var som nævnt præget af naturvidenskabens fremmarch og modernisering af samfundet inden for en række områder. Lægerne stod centralt i udviklingen, hvad det sociale og sundhedsmæssige domæne angik, og ungdommens sundhed og hygiejne blev i stigende grad af samfundet og ikke mindst lægerne selv anset som en sag, de burde forholde sig til og tage sig af. Den samme ungdom ønskede gymnastikpædagogerne imidlertid også at give større sundhed og bedre hygiejne samt i tilgift en harmonisk kropsdannelse og et mentalt styrket 
»indre«. Der var således på den ene side tale om, at lægerne og pædagogerne havde et fælles interesseområde, men på den anden side også et muligt konfliktområde med kamp om definitionsmagten.

Kampen endte som nævnt med Lindhardfløjens sejr, der dermed både vandt retten til at definere, hvad videnskabelighed og sundhed omfattede inden for idrætsområdet, og samtidig sikrede, at den praktiske idrætsundervisning på Statens Gymnastikinstitut blev underlagt universitetets indflydelse. Den svenske gymnastik måtte stort set opgive sine sundhedsvidenskabelige aspirationer og nøjes med at finde sit ståsted inden for det pædagogiske domæne. Her havde den trods alt været hele tiden, og kunne man ikke videnskabeligt bevise, at gymnastikudøvelse i sig selv skabte indre og ydre sundhed, kunne man stadig uantastet hævde, at gymnastikken og idrætten generelt var et glimrende opdragelsesmiddel (Jørgensen, 1998a, s. 139). Symbolsk for de nye magtforhold blev Lindhardt fra 1930 til 1938 også leder for Statens Gymnastikinstitut. Instituttet blev således ikke nedlagt, og idrætten bevarede sin plads i den højere uddannelse, men helt frem til ca. 1980 var pædagogikken reelt det eneste humanistiske teoriområde $\mathrm{i}$ et rent naturvidenskabeligt regi, hvor processerne i den arbejdende muskelcelle var et centralt idrætsligt forskningsområde.

\section{FYSIOTERAPIEN}

I det følgende vil betegnelsen fysioterapi (se note 1) og fysioterapeut for det meste blive anvendt. Udviklingen vil blive fulgt frem til 1928, hvor uddannelsen af fysioterapeuter blev ændret, moderniseret og forlænget (Betænkning nr. 919, 1981, s. 28).

Fysioterapi i institutionaliseret og organiseret

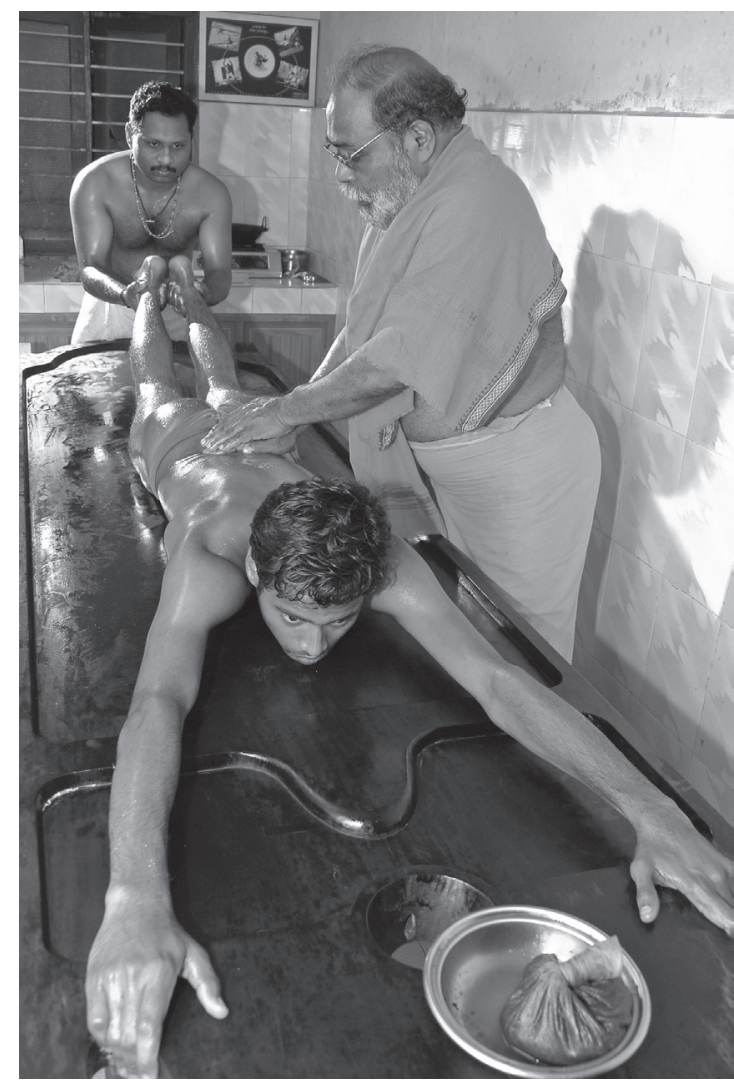

Gymnastik, fysioterapi og kiropraktik etableredes i Danmark ca. 1900-1930. Fælles for de tre aktiviteter/behandlingsformer var en overbevisning om, at man gennem arbejde med ryggen kan helbrede eller forebygge kroppens sygdomme og skavanker samt forbedre eller forskønne legemet. I andre kulturkredse har man gennem flere tusinde år anvendt sammenlignelige behandlingsformer. F.eks. bygger indisk marma terapi (på fotoet i form af strækmassage) på meget gamle teknikker.

form blev med sikkerhed udøvet på Klampenborg Badeanstalt i 1886, hvor man ansatte en sygegymnast. Det passer godt med, at den moderne fysioterapis fremkomst er blevet knyttet til den badekultur, der opstod blandt den euro- 
pæiske overklasse i løbet af det 19. århundrede (Danske Fysioterapeuter, 1993-6, s. 8). Inden Klampenborg havde enkelte læger herhjemme tilbage fra 1870erne selv givet massage til deres patienter eller oplært assistenter, der kunne gøre det. Fra 1888 blev en række kurser oprettet og nedlagt, men fra 1933 var der kun et tilbage, Teilmans kursus fra 1902, som i vore dage hedder Fysioterapiskolen i København (Agersnap, 1968, s. 218-224).

Uddannelsen i massage og sygegymnastik blev fra begyndelsen betragtet som særligt egnet for kvinder. Uddannelsens længde varierede, men landede ret hurtigt på 11/2 år, en længde den havde til 1928-reformen, der satte den op til to år. Indholdet var praktisk betonet og havde tilknyttet praktik. Omkring 1914 var der blevet fundet en fast form, hvor der især blev undervist $\mathrm{i}$ anatomi, fysiologi, sygegymnastik, massageteori og palpationslære, og hvor praktiktiden udgjorde seks mdr.

Selve det fysioterapeutiske arbejde var ca.1900 præget af hydroterapi, termoterapi, massage, sygegymnastiske øvelser og kulbuelys Omkring 1. verdenskrig blev nye aktiviteter indført, f.eks. respirationsfysioterapi, optræning og traktionsbehandling. I løbet af 1920erne blev yderligere tilføjet f.eks. elektroterapi og scoliosebehandling.

\section{DEN VIDENSKABELIGE FUNDERING OG FORHOL- DET TIL PATIENTERNE}

Fysioterapeuterne havde som antydet to forskellige faglige udgangspunkter for ca. 100 år siden. Enten havde man sin baggrund som massør eller som sygegymnast, ofte med uddannelse i Sverige. Forskellen mellem at være massør eller sygegymnast var ikke nødvendigvis særlig stor; begge grupper anvendte såvel massage som gymnastik i behandlingen. En forskel kunne dog være, at en sygegymnast anvendte endnu flere gymnastiske øvelser i behandlingen af patienterne end massøren, og at øvelserne ofte ikke kun tog udgangspunkt i sygegymnastikken, men også i den almindelige (svenske) gymnastik, som den blev udøvet i gymnastikforeningen eller i skolen (Danske Fysioterapeuter, 1993-6, s. 8).

Organisationerne for de "svenske» sygegymnaster i Danmark forsøgte lejlighedsvis dels at få afskaffet massørbetegnelsen og dels også at få indført den almindelige gymnastik. I 1913 foreslog de således det såkaldte Massageudvalg at indføre tvungen undervisning i mindst fire timer om ugen i svensk gymnastik med tilhørende kommandoøvelser. I Sverige, der havde haft autorisation af fysioterapeuter siden 1887, og som havde den mest velorganiserede uddannelse inden for området i Europa, var den almindelige gymnastik, kaldet friskgymnastikken, og sygegymnastikken, ikke adskilt i uddannelsen (Agersnap, 1968, s. 175). Det blev den reelt i 1934, men formelt først i 1959 (Lindroth, 2004, s. 73). Forslagsstillerne mente, at sygegymnasten i den danske uddannelse burde lære »de vigtigste typiske øvelser og de forskellige Øvelsesgrupper at kende og lære at opstille en Timeseddel, saa at han bliver i Stand til at kunne lede et Motionshold«. Det ville give underviseren en bedre forståelse og et bedre overblik, end hvis han kun benyttede sygegymnastik: "Øjet (opøves) langt bedre end i Sygegymnastik til at se, om Øvelserne udføres med rigtig Form, hvad der er af den største Betydning for deres Virkning “ (Agersnap, 1968, ss. 192-193). De læger, der bedømte forslaget, mente dog, at selv om sygegymnaster på det personlige plan uden tvivl ville have gavn af friskgymnastik, så var det for meget at bruge fire timer om ugen på det $\mathrm{i}$ et $\mathrm{i}$ forvejen presset skema (Ibid., s. 191).

De svenskinspirerede sygegymnasters hen- 
vendelse kan også læses som et forsøg på en øget videnskabeliggørelse af fysioterapien via den svenske gymnastik. Tilhængerne hævdede som nævnt, at den hvilede på videnskabelig grund, hvilket lægerne tog klart afstand fra. Den svenske historiker Jan Lindroth har påpeget en række kendetegn ved agitationsteknikken hos tilhængerne af den svenske gymnastik. Han sporer et vist mål af fanatisme hos dem, idet det først og fremmest ser ud til at have været en nærmest hellig pligt for dem at: »kompromisslöst sluta upp kring de lingska principerna i allmänhet og det lingianske system i synnerhet « (Lindroth, 2004, s. 147). På den baggrund kan de svenskinspirerede sygegymnasternes forslag i 1913 dels ses som en opfyldelse af "pligten" til at promovere og forsvare svensk gymnastik, dels som et forsøg på at styrke fysioterapiens videnskabelighed og anseelse. Samtidig er henvendelsen selvfølgelig også en indirekte faglig kommentar til kvaliteten af de fysioterapeuter (massørerne), der ikke magtede eller benyttede de svenske teknikker. Uanset om man var massør eller sygegymnast med de forskelle, som det kunne indebære, var den grundlæggende tilgang til såvel behandling som patient dog sammenlignelig. Der var tale om en udpræget symptomlindrende behandlingsform, der udførtes efter lægelig diagnose og ordinering, sjældent stillede krav til patienten og ikke var baseret på dennes aktive deltagelse.

\section{FYSIOTERAPIEN OG LAEGERNE}

Netop forholdet til lægerne adskilte klart fysioterapien fra gymnastikken og kiropraktikken. Fysioterapien blev organiseret i Danmark i årene omkring 1900, hvor både autorisation, uddannelsessteder og faglige organisationer opstod og hurtigt kom under kontrol af lægeverdenen. Fysioterapeuterne dannede i 1909 Dansk Massage- og Sygegymnastik Forening, hvor det blev stillet som hovedkrav til medlemskab, at man skulle være faguddannet og kun ville behandle patienter efter lægelig ordination. Samme år blev Loven om Sundhedsvæsenets Centralstyrelse vedtaget, og den placerede massører under Sundhedsstyrelsen. I 1914 blev området, på fysioterapeuternes eget initiativ, underlagt lægelig kontrol, idet et udvalg bestående af fem læger, Massageudvalget, fik som opgave at "varetage den almindelige Lægeforenings Interesser i Spørgsmål vedrørende Massage og Sygegymnastiks Udøvelse ved Ikke-Læger« (Dansk Massage, 1913, nr. 4). Udvalget udstedte autorisation til såvel fysioterapeuter som fysioterapeutskoler efter bedømmelse. En egentlig statsautorisation for fysioterapeuter blev først opnået i 1968 (Flindt-Jensen og Nielsen, 2002, s. 18-21).

I 1918 lykkedes det at organisere massører og sygegymnaster i én forening, Den almindelige danske Massageforening i daglig tale forkortet DADM. Foreningen fik hurtigt ca. 500 medlemmer, og lægerne var også her i kontrol, idet de to første formænd var mandlige overlæger. Med Massageudvalget bestående af læger som kontrolinstans og en overlæge som formand for DADM var hele fysioterapeutområdet hermed gennemreguleret og organiseret med lægerne solidt placeret ved rorpinden. Lægeverdenen fik kontrol over den organiserede del af området uden problemer med fysioterapeuterne, der tilsyneladende var lige så interesserede $\mathrm{i}$ at underlægge sig den lægelige autoritet, som lægerne var $i$ at udøve den.

Imidlertid fik fysioterapeuterne også noget ud af deres tilsyneladende underkastelse. De "lånte en autoritet fra lægerne, der kunne bruges over for den underskov af rene kvaksalvere, halvstuderede røvere og prostituerede, der kald- 
te sig massører eller (franske) massøser, og som ofte lovede forbløffende virkninger af deres massage. Massør var ingen beskyttet titel, og den tvivlsomme del af branchen kunne reelt kun rammes, hvis det gik så galt, at kvaksalveriloven af 1794 kunne anvendes. Det var vigtigt over for offentligheden at kunne udparcellere den slags folk og selv fremstå som en anerkendt og etableret del af sundhedsvæsenet. Et særligt problem var de mange underbetalte massører, herunder de såkaldte menighedssygeplejersker i landdistrikterne, der på baggrund af få måneders kursus tog arbejdet og dermed brødet fra de organiserede fysioterapeuter med ca. 11/2 års uddannelse bag sig. Det var fysioterapeuternes forventning at med den tætte tilknytning, de frivilligt havde søgt til lægerne, ville disse leve op til visse forudsætninger. Først og fremmest forekom det fysioterapeuterne indlysende, at når de havde indvilliget $\mathrm{i}$ kun at behandle patienter efter lægelig ordination, så burde lægerne som modydelse også kun henvise til autoriserede fysioterapeuter. Trods flere forsøg lykkedes det først at få dette krav vedtaget i 1951 (Agersnap, 1968, ss. 216-218).

Den tredje formand for DADM, Marie Møller (1923-1940), var ikke alene selv fysioterapeut, hun var også kvinde. Dermed skitseres en yderligere grund til, at fysioterapeuterne først efter nogle år selv tog ledelsen over deres organisationer. Den kan måske findes i fysioterapeuternes køn. De var næsten alle kvinder, og den gældende diskurs på det tidspunkt har sikkert ikke været befordrende for, at de, der dårligt havde fået stemmeret, skulle kunne være i stand til at lede sig selv eller andre. At de ikke kunne det, ville være helt i overensstemmelse med den "særartstankegang«, der herskede i samfundet. Ifølge den er kønnenes forskellige evner betinget af deres biologiske køn, og kvinder har således na- turlige anlæg for omsorgsopgaver f.eks. i forbindelse med sygepleje. Og ikke for fagpolitik og ledelse. Det var derimod vigtigt, at de var dannede. I lighed med, hvad der gjaldt for sygeplejersker, var det af afgørende betydning, at: "Massører og Sygegymnaster var i besiddelse af en vis Kultur og Dannelse«. Især unge kvinder fra gode kår, mente man, kunne leve op til de krav (Flindt-Jensen og Nielsen, 2002, s. 14-15). Det skal dog understreges, at jeg ikke har fundet materiale, der direkte kobler massørernes køn til deres arbejdsområdes organisering.

Der var trods alt måde med fysioterapeuternes underkastelse over for lægeverdenen, de havde også en faglig stolthed at tage vare på. Det kom bl.a. frem i lønkampen, hvor de savnede lægernes støtte, ${ }^{7}$ og i reaktionen på et forslag som formanden for DADM, overlæge Erik Faber, stillede i 1921. Han foreslog, at fysioterapeuter også skulle undervises i sygepleje, laboratorieundersøgelser, bogføring, maskinskrivning og journalføring med det argument, at den praktiserende læge havde brug for en bredt uddannet massør. Her slog DADMs medlemmer bremserne i over for deres formand. De var fysioterapeuter, ikke lægeassistenter!

Lægerne havde ikke overdreven respekt for fysioterapeuternes evner som fagpersoner ud over et rent praktisk niveau. Udgangspunktet for den fysioterapeutiske behandling fandt lægerne $\mathrm{i}$ et behandlingsparadigme, der i tidens ånd så kroppens fysiske skavanker i en apparatfejlmodel med deraf følgende mekanisk behandlingsmetode. Ifølge lægerne skulle fysioterapeuterne først og fremmest beherske et håndværk og ikke beskæftige sig med selvstændig behandling. En kendt tysk læge hævdede ligefrem, at uddannelsen til fysioterapeut burde være ganske kort og udelukkende praktisk. Hvis fysioterapeuterne kun lærer de tekniske hånd- 
greb, der skal bruges, men: „i øvrigt intet forstår af, hvad det er, der foregaar, vil de ikke let fristes til at drive Terapi paa egen Haand", mente han (Agersnap, 1968, ss. 182). Så vidt gik langtfra alle læger, men da fysioterapeuterne i 1921 ansøgte Massageudvalget om at få optaget undervisning i elektroterapi i uddannelsen, blev dette afvist: Elektricitetsbehandlingen bør forbeholdes Lægerne, og vi ønsker ikke at give Massørerne flere Fjer i Hatten, end de har. Det, Massørerne har lært godt og grundigt på Kurserne, det skal de udøve, men ikke mere« (Flindt-Jensen og Nielsen, 2002, ss. 27). Først med nyordningen af uddannelsen i 1928 blev undervisning i elektroterapi indført.

Fysioterapeuterne har i årenes løb løsrevet sig fra lægernes dominerende indflydelse og har for længst defineret og dannet deres egen faglighed. Med statsautorisationen i 1968 forsvandt de sidste principielle bindinger til lægerne, og i vore dage kan fysioterapeuter både diagnosticere og behandle. ${ }^{8}$ Det er nyt herhjemme, at fysioterapeuternes uddannelse nu er blevet tilknyttet et universitet med professorer, fysioterapeutisk forskning, etc. Det er imidlertid en udvikling, der ikke er usædvanlig i andre lande. I den sammenhæng kan nævnes, at det ikke kun er i Sverige, at gymnastik/idræt og sygegymnastik oprindeligt blev placeret i samme institut. I vore dage er der således flere østeuropæiske universiteter, hvor der findes institutter for "Idræt og fysioterapi«.

\section{KIROPRAKTIKKEN}

Spinal manipulation af det menneskelige bevægeapparat kan spores tilbage til en række kulturer. Kiropraktikken i dens moderne form er imidlertid opstået i USA, hvor den på nærmest mytisk vis dateres til præcist den 18. september 1895, hvor Daniel David Palmer foretog sin før- ste spinale korrektion. Palmer, der havde en fortid som magnetisk healer, professionaliserede og systematiserede den spinale manipulation, og kiropraktik er i vore dage blevet en af de største, mest kendte og velordnede af de professioner, som eksisterer sideløbende med den traditionelle lægegerning, og som beskæftiger sig med helbredelse. Det har dog ikke i sig selv betydet en hurtig og smertefri anerkendelse af faget. Gennem kiropraktikkens forholdsvis korte historie har det ikke været noget let job for tilhængerne at promovere et behandlingssystem, der var delvist rodfæstet i, hvad diverse lægelige autoriteter ofte har opfattet som mystik i sammenligningen med mainstream medicin og etableret videnskabssyn.

\section{DEN VIDENSKABELIGE FUNDERING OG FORHOL- DET TIL PATIENTEN}

"Forholdene i Amerika kompliceres noget ved, at de saakaldte "Osteopather" - en Slags Sygegymnaster eller Massører, der arbejder paa Basis af nogle fantastiske ensidige Teorier - for sig kræver Autorisation som selvstændige Terapeuter og synes at have en vis Stemning for sig i denne Henseende« (Agersnap, 1968, 177).

Citatet er fra en udredning, som et udvalg af læger i 1910 fremlagde, og hvor de blandt andet havde undersøgt massagens og sygegymnastikkens stade og stilling i flere forskellige lande. Det fremgår dels, at forholdene i USA ikke imponerede dem, og dels at de åbenbart forvekslede kiropraktik med fysioterapi. Alene med det udgangspunkt, at kiropraktik åbenbart var dårlig fysioterapi, er det ikke underligt, at kiropraktikken ikke blev modtaget med begejstring af lægerne, da den dukkede op i Danmark ca. 10 år efter.

Oven i købet fandt helbredelse af sygdom ikke 
sted i traditionel lægelig forstand, men ved at skabe "balance« eller »normalitet" i kroppen gennem manuel bearbejdelse af bevægeapparatet. Ved at korrigere for anormalitet i skelettet - først og fremmest spinalt - kan man opnå helbredende og sundhedsfremmende effekter, hævdede kiropraktorerne. Den vej til sundhed og helbredelse følger mange kiropraktorer også i vore dage, hvor der dog er forskellige meninger om, hvad kiropraktorarbejdet indeholder. I Danmark har de fleste kiropraktorer f.eks. en meget mere traditionel lægevidenskabelig tilgang til faget end for 80 år siden. ${ }^{9}$

Også kiropraktorernes patientforhold var anderledes end lægernes, idet udgangspunktet var dialog og en idé om, at patienter også kan producere viden. På et tidspunkt hvor patienter normalt ikke skulle være aktive hos lægen, der jo var den undersøgende ekspertpart, inddrog kiropraktorerne således deres patienter i undersøgelsen ud fra en idé om, at patienter udmærket vidste, hvad de fejlede. Og hvor kiropraktikken tilbød en let, forståelig og sammenhængende teori om sygdom og helbredelse, hvor smerten blev lokaliseret og talt om, var mødet med den traditionelle læge ofte mere diffust for patienten.

Den første kiropraktiske klinik i Danmark åbnede i 1920, og patienttilstrømningen bevirkede, at klinikken kunne udvide allerede samme år. Bortset herfra startede kiropraktorerne på mange måder fra scratch. Få vidste noget om kiropraktik herhjemme, og selv udtalen af "kiropraktor « måtte man forklare den undrende offentlighed. Det hjalp dog noget, da patientforeningen, Chiropractisk Forening for Danmark, med ca. 300 medlemmer blev stiftet i 1925. Den var fra start meget aktiv og mediebevidst og havde flere af samfundets spidser i bestyrelsen og en folketingsmand som formand. I vore dage er kiropraktikken en fuldt accepteret del af sundhedssystemet, den er underlagt Sundhedsvæsenets Patientklagenævn, og der gives offentligt tilskud til kiropraktisk behandling og patientforeningen, Kiropraktik \& Sundhed. Denne har p.t. ca. 17.000 medlemmer, hvilket i øvrigt er en kraftig tilbagegang i forhold til dengang, da kampen for anerkendelse stod på sit højeste. ${ }^{10}$

I 1994 blev der oprettet en universitetsuddannelse til kiropraktor på Syddansk Universitet i Odense med en klinisk overbygning på Ringe Sygehus. Forskningsprojekter er siden blevet gennemført. Der er oprettet kiropraktiske professorater, gennemført ph.d.-studier og snesevis af kandidater er blevet færdiguddannet de sidste ca. 10 år, og et flertal af de kiropraktorer, der arbejder i Danmark, er uddannet i Odense.

\section{KIROPRAKTIKIKEN OG LAEGRNE}

Den første kiropraktor, der åbnede klinik, havde, som så mange efter ham, fået sin uddannelse i USA. Han mødte straks hård kritik fra lægestanden og dele af offentligheden, der ikke tøvede med at bringe kvaksalveriloven $i$ anvendelse. Det, der umiddelbart slog hovedet på sømmet, var, at kiropraktorerne hævdede at kunne diagnosticere, behandle og helbrede sygdom, hvilket var lægernes privilegium. I aviserne blev der yderligere beskrevet, hvorledes patienter blev klædt nøgne og pryglet som led i behandlingen, og allehånde rygter om, hvad kiropraktik gik ud på, cirkulerede. Kiropraktorer blev en overgang ligefrem kaldt "prygledoktorer«. Klinikken var imidlertid en stor succes med mange patienter, og for at få arbejdsro for lægeverdenens angreb ansatte kiropraktoren en læge for derved at leve op til kravet om, at kun autoriserede læger i princippet måtte diagnosticere patienter. Det varede dog kun kort tid, før lægeforeningen anklagede lægen for at overtræde lægeloven ved dette samarbejde, men i man- 
ge år fremover var det en almindelig procedure, at læger var tilknyttet klinikkerne, og først når en læge havde undersøgt patienten, kunne kiropraktoren påbegynde arbejdet. Med Lægeloven af 1934 fik kiropraktorer lov til selv at tage syge i behandling uden forudgående lægeundersøgelse af patienten. På det tidspunkt var der ca. 25 praktiserende kiropraktorer i landet (Gautvig og Hviid, 1975, s. 92).

Kiropraktorernes argumentation for behandlingens udførelse og virkning lå ret langt fra mainstream sundhedsvidenskab, og at de også hævdede, at sygdomme som f.eks. diabetes kunne behandles ved manipulation, gjorde ikke sagen bedre. Lægerne tog kraftigt afstand fra den slags tøjeri, men det var ikke muligt at lukke sagen endsige at få ret. Kiropraktorerne var veluddannede og teoretisk skolede, de brugte aktivt deres amerikanske baggrund til at præsentere sig selv som moderne behandlere, der tilbød en mere effektiv behandling end den traditionelle lægelige. Kiropraktorerne søgte ligestilling med lægerne i forhold til sundhedssystemet med udgangspunkt $\mathrm{i}$ to præmisser. For det første at kiropraktik var rigtig sygdomsbehandling, ganske vist forskellig fra lægernes, men ikke mindre værdifuld, og for det andet at lægerne ikke skulle have lov til autoritativt at afgøre kiropraktikkens værdi (Bak-Jensen, 2004, s. 267).

Lægerne havde af flere grunde svært ved at bekæmpe kiropraktorerne. På den ene side var de uortodokse via deres uddannelse i USA, de havde en business-like indfaldsvinkel til sundhedspraksis, og deres behandlingsmetoder var helt anderledes. På den anden side havde de teoretisk funderede metoder, en omfattende uddannelse, et velfungerende netværk med organisationer og patientforening, de havde en (amerikansk) doktortitel, deres klinikker var indrettet som almindelige medicinske klinikker, og de havde hvid kittel som arbejdsuniform. Det var kort sagt ikke nemt for lægerne at komme effektivt efter kiropraktorerne med kvaksalveriloven $\mathrm{i}$ hånden. Her var ikke tale om traditionelle kvaksalvere, der tilbød fantasifulde behandlinger med mirakuløse virkninger mod uhelbredelige sygdomme. Selv om der blev gjort mange forsøg, førte anklager om kvaksalveri over for kiropraktorer sjældent eller aldrig til noget ved domstolene. ${ }^{11}$

Kiropraktikkens forhold til den etablerede lægestand og det offentlige sundhedsvæsen er præget af kampen for statsautorisation, og på det område lykkedes det lægebranchen at slå bremserne i og bevare kontrol; først i 1992 fik kiropraktorerne trods flere forsøg statsautorisation, og overgik fra kvaksalverilovgivningen til Kiropraktorloven. Det var 25 år efter, at fysioterapeuterne fik statsautorisation. De forsøgte første gang i 1927, da der var 11 kiropraktorer i Danmark. Ministeriet for Sundhedsvæsenet gav afslag uden begrundelse. Siden gik kiropraktorerne også uden om det etablerede sundhedsvæsen og direkte til offentligheden og folketingets politikere bl.a. ved hjælp af den aktive patientforening, der f.eks. i 1941 indsamlede over 100.000 underskrifter i et forsøg på at få kiropraktik berettiget til sygekassestøtte (Gautvig og Hviid, 1975, s. 88-92). Lægerne fik ikke udryddet kiropraktorerne fra jordens overflade, som en ilter læge foreslog på et tidspunkt, men de fik udskudt, at kiropraktorerne blev anerkendt af og i det etablerede sundhedsvæsen.

Når man ser på det meget lille antal kiropraktorer, der var tale om i perioden, de var aldrig over 25, forekommer lægernes reaktion overdreven. Hvad var de egentlig bange for? Som Mary Douglas argumenterer, handler frygt også om, at grænser trues, og at ting, der burde holdes adskilt, bliver bragt sammen. ${ }^{12}$ Kiropraktorerne 
var som nævnt på mange måder både forskellige fra lægerne og dog ligesom dem. Det gjaldt såvel i adfærd som i viden og i metoder, og det skabte forvirring i sig selv. Særlig stor forvirring og harme skabte påstanden om, at manuelt produceret viden var et ligeværdigt alternativ til den spekulative og teoribaserede viden, der karakteriserede lægerne (Bak-Jensen, 2004, s. 218). Desuden og ikke mindst havde kiropraktorerne et helt andet patientforhold, end lægerne havde. At tale med patienten, røre ved patienten, aktivere patienten er måske ikke usædvanligt i vore dage, men det var det i 1920'erne, og det gjorde kiropraktorerne. ${ }^{13}$

Det er blevet påpeget, at de tidlige kiropraktorers samlede legitimeringsstrategier rokkede ved datidens forståelse af sygdom, sundhed, patientrelation og for evaluering af viden (Ibid., s. 270-271). De skabte i Douglas' forstand kaos inden for centrale områder i relation til forståelse af sygdom, sundhed, diagnosticering og patientlæge forhold. Set ud fra det synspunkt og kombineret med kiropraktorernes store evner til at skabe opmærksomhed via medier og patientforening var der mere på spil for lægerne, end at en håndfuld alternative behandlere søgte at etablere sig.

Kiropraktorerne fik som nævnt først sent statsautorisation, og det er stadig muligt at finde (også voldsomme) angreb på kiropraktisk praksis (Skeptica, 2009, del 5). Alt i alt er kiropraktikken dog en bredt accepteret behandlingsform i vore dage. Det hænger bl.a. sammen med, at den kiropraktik, der undervises og forskes i for tiden, har flyttet sig meget i forhold til Palmers udgangspunkt. F.eks. hviler instituttets kiropraktik i Odense på et rent naturvidenskabeligt grundlag, hvilket bl.a. kan ses ved, at fakultetets bacheloruddannelser for såvel kiropraktorer som læger i stort omfang er identiske.

\section{KONKLUSION}

Lægeverdenen forholdt sig forskelligt til de tre aktiviteter, svensk gymnastik, fysioterapi og kiropraktik, og de tre aktiviteter agerede forskelligt i mødet med lægerne i perioden ca. 19001930. Den svenske gymnastik påståede videnskabelighed blev skudt ned af den moderne naturvidenskab, der vægter eksperiment i laboratoriet frem for erfaring i gymnastiksalen. Fra ca. 1920 måtte faget især finde sin plads inden for det pædagogiske domæne, hvor dets opdragelsesmæssige kvaliteter blev fremhævet. Fysioterapien var ikke i samme klemme. Dels accepterede fysioterapeuterne, måske med undtagelse af sygegymnaster med baggrund i uddannelse fra Sverige, at fagets udgangspunkt ikke var videnskab, men snarere håndværk. Dels var fysioterapeuterne under "kontrol" af lægerne, hvad angår autorisation, uddannelse og (i en periode) ledelse af den faglige forening. Kiropraktorerne blev inddraget i en årelang kamp med lægevidenskaben, en kamp, man kan finde udløbere af den dag i dag. På det formelle plan stod kampen om anerkendelse via opnåelse af statsautorisation, men reelt var der i lige så høj grad tale om en definitionskamp vedrørende forståelse af sundhed, sygdom og videnskabelighed samt behandlerens forhold til patienten.

Alle tre aktiviteter ønsker, med lidt forskellig pointering, at opøve, bibeholde eller genskabe funktioner i bevægeapparatet, og der lægges vægt på kroppens udseende og holdning. Det minder om indholdet $\mathrm{i}$ »ortopædi «. Den eksperimentelle fysiologi, som er den form for videnskab, der kommer nærmest denne artikels lægevidenskab, interesserer sig især for kroppens indre processer. Den blev udviklet senere end ortopædien og havde som videnskab betragtet 
stor ekspansionskraft og forklaringskraft ca. 1900.

På den måde kan antydes, at gymnastikken, fysioterapien og kiropraktikken ikke kun blev søgt kørt ud på et sidespor af den moderne lægevidenskab på grund af lægernes autoritet og de tre aktiviteters egen vidtløftighed med hensyn til påståede virkninger, der kunne »dokumenteres « videnskabeligt. Tiden var med fysiologien som videnskabelig retning snarere end ortopædien. Det er den muligvis stadig, men i årenes løb har resultaterne af en række undersøgelser og forsøg flyttet grænserne dels for fortolkningen af videnskabelighed dels for viden om, betydningen af og sammenhængen mellem krop, bevægelse og sundhed. Det er en viden, som ikke var til rådighed for 100 år siden. $\mathrm{Og}$ det er en viden, der dækker alle tre aktiviteter, og som demonstrerer, at basal forskning i træning og fysisk aktivitet kan gå hånd $\mathrm{i}$ hånd med interventions- og implementeringsforskning samt undersøgelse af best practice. På den baggrund kan det være naturligt, at de tre aktiviteter (dog med gymnastikken erstattet af idræt) i vore dage har fundet sammen på et universitet.

\section{LITTERATUR:}

Agersnap, R. (1968). »1918-1968«. (I Danske Fysioterapeuter 1968 (scernummer), s. 170-251)

Bak-Jensen, S. T. (2004). Manipulative Exclusivity: The Legitimation Strategies of Early Danish Chiropractors, 1920-1943. Upubliceret ph.d.afhandling. Københavns Universitet

Betænkning om uddannelse af ergoterapeuter og fysioterapeuter. Betænkning nr. 919-1981
Danske Fysioterapeuter - 75 års jubilæum 1993-6

Danske Fysioterapeuter - 80 års jubilæum 1998-11

Douglas M. (1966). Purity and Danger: An Analysis of Concepts of Pollution and Taboo. London: Routledge

Foucault M. (1994). Overvågning og straf. København: Det lille Forlag

Foucault M. (2000). Klinikkens fødsel. København: Hans Reitzel

Flindt-Jensen, N. og Nielsen, T. A. (2002).

Fysioterapiuddannelsen $i$ København - 100 år $i$ gode hoender. Fysioterapeutskolen i København

Gautvig, M. og Hviid, Aa. (1975). Kiropraktiki Danmark. København: Landsforeningen til Kiropraktikkens Fremme

Gymnastikkommissionen (1899). Haandbog $i$ Gymnastik, København: Forlaget J. Frimodt

Hartling, O. (2009). Alternativ medicin, del 5. I Skeptica - Kritisk forum for paranormale fanomener, pseudovidenskab og overtro. januar, 2009. Fra www.http://skeptica.dk/artikler/?p=355

Jørgensen, P. (1998a). Ikke at more, men at opdrage. I I. Berg-Sørensen og P. Jørgensen (red.) Een Time Dagligen - Skoleidrcet gennem 200 år. Odense: Odense Universitetsforlag

Jørgensen, P. (1998b). Gymnastik og sport i den danske skole ca. 1900-1960. Idraetshistorisk Årbog 1998. (s. 85-150) 
Korsgaard, O. (1982). Kampen om kroppen. København: Gyldendal

Korsgaard, O. (1986). Krop og Kultur - andelsbøndernes gymnastik mellem almuens leg og borgerskabets sport. København: Gyldendal

Lindroth, J. (2004). Ling - Från storhet till upplösning - Studier i svensk gymnastikhistoria 1800-1950. Stockholm: Bokförlag Symposion

Meeker, W. C. og Haldeman, S. (2002). Chiropractic: A Profession and the Crossroads of Mainstream and Alternative Medicine. I Academia and Clinic - Annals of Internal Medicine 2002-136(3).(s. 216-227)

Rosenbeck, Bente (2009). Den moderne videnskabs gennembrud i 1800-tallet. I A. L. Poulsen m.fl. (red.) Forskning $i$ bevagelse - Et nyt forskningsfelt $i$ et 100-årigt perspektiv. (s. 14-34). København: Museum Tusculanum

Rud, N. (1906). Gymnastisk Selskabs Aarskrift, 1906. (s. 78)

Tidsskrift for Dansk Massage og Sygegymnastik forening nr. 4, 1913

Trangbæk, E. (1987). Mellem leg og disciplin. Gymnastikken i Danmark i 1800-tallet. Åbybro: Forlaget DUO

Trangbæk, E. og Jørgensen, K. (2009). Striden mellem Johannes Lindhard og K.A. Knudsen. I A. L. Poulsen m.fl. (red.) Forskning $i$ bevaegelse - Et nyt forskningsfelt $i$ et 100-årigt perspektiv. (s. 92-101). København: Museum Tusculanum 


\section{NOTER}

1. Betegnelsen fysioterapi blev først taget officielt $i$ brug herhjemme i 1954, men selve aktiviteten er ca. 100 år ældre og blev i denne artikels periode kaldt "massage« eller "sygegymnastik".

2. Svensk gymnastik og sygegymnastik er dog blevet beskrevet sammen. Det skyldes især de to aktiviteters fælles baggrund i P.H. Lings gymnastik.

3. Begrebet "definitionsmagt» er en del af denne artikels forståelsesramme og kan ses i relation til Foucaults undersøgelser af sammenhængen mellem magt og viden. I fremvæksten af den moderne vestlige stat og økonomi spiller viden en fundamental rolle i forhold til definitionsmagt og normativitet. Foucault ser menneskets omgang med viden som underlagt et vidensregime, der fungerer som et implicit tvangssystem for måden at vide noget på. At kunne definere diskursen kan sidestilles med det at definere virkeligheden. Foucault kredser om disse emner ved adskillige lejligheder, f.eks. i Overvågning og straf (1994).

4. Spørgsmålet har især beskæftiget Ove Korsgaard, f.eks. i: Korsgaard, O. (1986) Krop og Kultur. Det var ikke på grund af indholdet i sig selv, at den svenske gymnastik blev indført, idet der strukturelt ikke var den store forskel mellem den (tysk/danske) gymnastik, man allerede havde, og den nye. I begge gymnastikforme stod f.eks. gang, løb, armstrækning, armbøjning, kropsbøjning og -vridning centralt.

5. Intentionen var, at begge køn fra første til sidste klasse i hele skolesystemet skulle have svensk gymnastik i de fleste idrætstimer. Pigerne i folkeskolen fik dog først obligatorisk skoleidræt med reformen i 1937.
6. I virkelighedens verden var det imidlertid begrænset, hvor dominerende den svenske gymnastik var. Den mødte modstand hos mange lærere og elever ikke mindst i gymnasieskolen (Jørgensen, 1998b, s. 56).

7. I 1919 kunne fagbladet påvise det urimelige i, at en lærerinde fik ca. 60 \% mere i løn end en fysioterapeut. Danske Fysioterapeuter, 1998, s. 10

8. F.eks. er Muskuloskeletal Fysioterapi et fysioterapispeciale, der omhandler såvel diagnostik som forebyggelse og behandling af lidelser i ryg og bevægeapparat (www. muskuloskeletal.dk).

9. Spinal manipulation er stadig den mest centrale behandlingsform i klinikken. Der eksisterer et utal af justeringsteknikker, hvilket i sig selv afspejler variationen i den kiropraktiske praksis (Meeker og Haldeman, 2002, s. 218-219).

10. I 1970'erne havde patientforeningen, Landsforeningen til Kiropraktikkens fremme, ca. 50.000 medlemmer (Gautvig og Hviid, 1975, s. 1).

11. Der blev rejst en række sager mod kiropraktorer med ud gangspunkt i kvaksalveriloven af 1794. Den hårdeste dom lød (1926) på seks ugers fængsel efter et påstået dødsfald som følge af forkert kiropraktik. Denne dom blev ved landsretten året efter ændret til en bøde på $200 \mathrm{kr}$., og som regel var der tale om frifindelser (Gautvig og Hviid, 1975, s. 91-92)

12. Med reference til Mary Douglas, f.eks. Purity and Danger (1966).

13. Foucaults værk, Klinikkens Fødsel (2000), kan ses som baggrund for denne argumentation. 